\title{
ENTREPRENEURSHIP AMONG STUDENTS: THE POTENTIAL IN SERBIA
}

\author{
Dejan ĐORĐEVIĆ ${ }^{1}$, Dragan ĆOĆKALO ${ }^{2}$, Srđan BOGETIĆ ${ }^{3}$, Dragica IVIN ${ }^{1}$ \\ ${ }^{1}$ University of Novi Sad, Technical faculty "Mihajlo Pupin" in Zrenjanin, 23000 Zrenjanin, Đure Đakovica bb, \\ Republic of Serbia \\ ${ }^{2}$ University of Novi Sad, Technical faculty "Mihajlo Pupin” in Zrenjanin, 23000 Zrenjanin, Đure Đakovica bb, \\ Republic of Serbia. E-mail: cole@tfzr.uns.ac.rs \\ ${ }^{3}$ Belgrade Business School, 11000 Belgrade, Kraljice Marije 73, Republic of Serbia
}

Accepted 17 October, 2012

\begin{abstract}
The ambience where young people can be stimulated to start their own business is not developed enough in Serbia. Possible solutions can be education and encouragement of the young to start and perform their own business. Stimulating enterprising behaviour of the young is especially important in transitional countries faced with recession. The authors of this paper are analysing the necessity of implementing a modern enterprise concept on the territory of the Republic of Serbia with a special attention to the role of students and the opportunities of their involvement in enterprise activities. Espetially in this paper are compared and presented the results of three consecutive researches carried out among Serbian students.
\end{abstract}

Key words: entrepreneurship, knowledge, SMEs, young entrepreneurs.

\section{INTRODUCTION}

Global economic crisis has caused a lot of economic problems identical for most countries in the world. As a result national economies started transformation of their economic policies and they began the process of creation of new economic policy able to cope with changes on the market. One of the greatest world economic problems is unemployment which is rising and, therefore, its reduction by opening new possibilities for employment and encouragement of business startups represent the most challenging economic task in the future.

Encouraging opening of small and mid-size enterprises (SMEs) whose aim is reducing unemployment represents a new economic reciepe. In other words, the experiences of developed countries such as Italy, Germany, South Korea, USA and the others, have confirmed that it is a good direction which should be followed during recovery of national economies. The examples of Italy and Germany have become demonstrative - they show how to start economic development in damaged economies. However, the crucial fact in these countries was the existence of appropriate ambience which made possible promotion of effective entrepreneurship through:

- State support through institutions (relevant Ministries for Economy or Industry, Education, Science and Technology, Research and Development) for encouraging entrepreneurship;

- Creation of efficient legislation for the work of SMEs - setting laws/regulations related to entrepreneurship, especially for young entrepreneurs, reducing bureaucracy and administrative procedures as main obstacles for free entrepreneurship;

- The existence of institutions which are closely specialized for help and support to SME sector;

- The existence of a bank which directs its financial means to quality programs of the present and new SMEs;

- Cooperation with Universities and institutions whose aim is improving knowledge of entrepreneurs;

Encouraging the making of clusters as important institutions in impoving competitiveness of SME sector;

Encouraging establisment of incubators as crucial institutions for young entrpreneurs; 
- Cooperation of SME sector and big companies through cooperative relations;

- Encouraging entrepreneurship of the young through programs of support by Association of entrepreneurs, Chambers of Commerce and similar associations.

As we can see, the creation of entrepreneurial ambience requires the engagement of all participants on the market, especially the state. Namely, the state should found the system in which all elements will have the common aim related to entrepreneurial encouragement.

\section{ENCOURAGEMENT PROGRAMS FOR THE YOUNG ENTREPRENEURS IN EUROPEAN UNION}

European Union have understood that the results of global crisis negatively influence the economy of its members and the Union as well. As a solution for economic problems European Commission has created a strategy ',Europe 2020', wishing that EU economy becomes: intelligent, sustainable and comprehensive. The aim of these three segments is to provide EU and the member countries with high degree of employment, productivity and social cohesion. In the sphere of unemployment reduction EU Commission has scheduled promotion of business creation and self-employment. Moreover, there is a plan for modernization of public administration aiming at reduction of bureaucracy and making conditions for new business start up in the period of three days.

The program ,Europe 2020“is consisted of 7 holders and they are (European Commission 1, 2011, p. 4): digital agenda;young on the move; union of innovations; new industrial policy;new skills and new business; platform against poverty and resources efficiency.

The initiative "Young on the move"has the following aim - reducing the rate of unemployment of the young so it started cooperation with numerous institution in EU and created European network for employment of the young. This network has several pillars and they are (European Commission 1, 2011, p. 14): help in getting the first job and starting the career; support to the young in risky situations; providing an appropriate network of social security for young people;support to young entrepreneurs and self-employment.

According to the information of Eurostat for 2012, it can be concluded that the percentage of unemployment in EU is in permanent rise during the period from 2010 to 2012. Namely, the unemployment rate in EU 27, in February 2012 was $10.2 \%$ which represents a small increase comparing to the previous two years - 9.8\% (2011)and i 9.6\% (2010).The unemployment rate for the Eurozone countries in February 2012 was $10.8 \%$, which is for $0.5 \%$ more comparing to November 2011,or $0.8 \%$ comparing to November 2010 (Eurostat, 2012). In the Tables 1.and 2. We can see Table review of three countries with the lowest and highest rate of unemployment in EU.

According to the data from the previous three years ranking of the countries is similar, which points at the fact that increase of unemployment has lasted for several years. Opposite to EU, USA and Japan had fall in unemployment in 2011 and 2010. In other words, in 2010 the unemployment rate in USA and Japan was $9.8 \%$ and $5.1 \%$, while in the next year the unemployment decreased to $8.6 \%$ in USA and $4.5 \%$ in Japan.

The unemployment rate in the group of young people in EU is in permanent rise which indicates a systemic problem that European Commission is trying to solve. The data show that in 2012 the unemployment rate of the young in EU is $22.4 \%$, which is a small rise comparing to the previous two years: 2011. (2.3\%) and 2010 (21\%). The same situation is in Eurozone where we can notice a rising unemployment rate considering young people, in February 2012 it was $21.6 \%$, and in the previous two years $21.7 \%$ (2011)and 20\% (2010).

Table 1: Highest rate of unemployment (Eurostat, 2012)

\begin{tabular}{|l|c|}
\hline \multicolumn{1}{|c|}{ Country } & $\begin{array}{c}\text { Percentage } \\
\text { (February 2012) }\end{array}$ \\
\hline Spain & 23.6 \\
\hline Greece & 21 \\
\hline Lithuania & 15 \\
\hline
\end{tabular}

Table 2: Lowest rate of unemployment (Eurostat, 2012)

\begin{tabular}{|l|c|}
\hline \multicolumn{1}{|c|}{ Country } & $\begin{array}{c}\text { Percenage } \\
\text { (February 2012) }\end{array}$ \\
\hline Austria & 4.2 \\
\hline Holand & 4.9 \\
\hline Luxemburg & 5.2 \\
\hline
\end{tabular}

In the Tables 3 and 4 we can see the list of countries with the highest and lowest unemployment rates considering young people. According to them Spain and Greece have the highest unemployment rate. In comparison to the last two years this trend is 
constantly increasing. In 2010 this rate in Spain was $43 \%$ and in Greece $36.3 \%$, but in 2011 this relation in percentage has come closer, so in Spain it was $49.6 \%$, and in Greece $46.6 \%$.

What is new comparing to the previous two years is that Portugal appears as a country with high percentage of unemployment concening the young. In the last two years the third country according to high unemployment rate was Slovakia which has managed to reduce the unemployment rate in 2012.

Table 4 shows the countries with the lowest unemployment rate. It is interesting that Holand, Austria and Germany have had the lowest unemployment rate in EU in the last three years. However, inspite of the fact that these three countries have the lowest unemployment rate concerning the young in EU, this rate is constantly changing. In 2010 Germany had $9.1 \%$ which is for $1 \%$ more than Austria and $0.7 \%$ more than Holand. However, in the following year this relation was changed so in Germany the unemployment rate of the young was $8.1 \%$, which is $0.2 \%$ less than in Austria and $0.5 \%$ less than in Holand.

Table 3: Highest unemployment rate of the young (Eurostat, 2012)

\begin{tabular}{|l|c|}
\hline Country & $\begin{array}{c}\text { Percentage } \\
\text { (February 2012) }\end{array}$ \\
\hline Spain & 50.5 \\
\hline Greece & 50.4 \\
\hline Portugal & 35.4 \\
\hline
\end{tabular}

Table 4: Lowest unemployment rate of the young (Eurostat, 2012)

\begin{tabular}{|l|c|}
\hline Country & $\begin{array}{c}\text { Percentage } \\
\text { (February 2012) }\end{array}$ \\
\hline Holand & 9.4 \\
\hline Austria & 8.3 \\
\hline Germany & 8.2 \\
\hline
\end{tabular}

From these statistic data we can see that EU has had a serious many year problem with unemployment especially concerning the young. Global economic crisis has only forced member countries and EU itself to try to find ways for unemployment reduction. However, unemployment is not the only economic problem but the present business ambience which inhibits companies and influences their competitiveness.

In 2011 European Commission created an aid program for future and the present SMEs owners and big companies' owners in order to improve the state of EU economy. The program ''The program for competitiveness of companies and SME" has been focused on the following groups (European Commission 2, 2011, p. 1): entrepreneurs, especially SME which will benefit from easier access to financial means for financing their own business; citizens who want to start their own business and who face with difficulties during this process; authorities of member countres which will create and apply effective policy of reforms with great efforts.

The budget of this program is 2.5 billion EUR and its main aims are (European Commission 2, 2011, p. 1): improvement of the access to financies for SME in the form of capital and loans; improvement of the access to the market within EU and global market as well; promotion of entrepreneurship: the activities will include development of entrepreneurial skills and attitudes especially among new entrepreneurs, young people and women.

\section{STUDENTS AS ENTREPRENEURS IN SERBIA}

Since the early 1980s Serbian economy has had problems with improving quality and productivity. The productivity problem did not appear in Serbian economy only in the time of transition but it was present before, as well. These problems were the result of inappropriate business performance which was not based on market principles. Certain products had unjustifiably high prices which were not competitive on the world market. Therefore, Serbian companies reduced export prices in order to gain competitiveness on the world market, while Serbian customers had to pay this cost of unproductiveness through high prices. Old technology, poor quality, unattractive packaging and high prices are thus the main reasons for uncompetitive appearance of Serbian products on international market. (Đorđević et al., 2011)

In Republic of Serbia several researches have been carried out recently in order to get the attitudes of young people about entrpreneurship, business start up, the reasons for and against business start up. These researches are very important because they show certain failures on the side of the state in the fields of education, legislation and the work of institutions.

In November and December 2011 a research was carried out on the territory of 16 towns and municipalities in Serbia under the name ,The analysis of attitudes and opinions of the young in relation to business start up and implementation of socially responsible busines“. Within this research 
654 students from 19 to 27 years of age who were surveyed expressed their attitudes about own business start up, socially responsible business and competitiveness of domestic economy. In the last three years (2008, 2009 and 2010) similar researches were carried out which can serve as comparison and help in creating the picture of the relations of young people towards their own business start up.

According to research results from 2011, the majority of students, $76.88 \%$ of them, wanted to start their own business. These data are similar to the previous two researches (2008, 2009.and 2010) which showed high preference of the young to start their own business. The results from 2011 showed that private business represents: risk and uncertainty $(23.53 \%)$, challange $(21,93 \%)$, pleasure and selfconfirmation $(14.90 \%)$.

The interviewed students mainly agree (44.90\%) with the statement that private business is more successful than the one in other forms of ownership and that the people here still do not know real business possibilities of private companies $(32.92 \%)$. The interviewed students, $49.77 \%$ of them, agree with this statement which points at the need for promotion of successful entrepreneurs in Serbia in order to change certain sterotypes related to entrepreneurship and managing private companies.

The interviewed students are in most cases turned to their own financial means for business start up $(60.38 \%)$. The reason for such attitude is a consequence of their insufficient trust in banks and other institutions which offer financial means for business start ups. As a support to this goes the attitude of the interviewed students $(5.74 \%)$ that start up loans of commercial banks are not favourable. Namely, they think that start up loans of commercial banks are overloaded with high interest rates $(80.38 \%)$ and a long process for getting the means $(14.42 \%)$. The data from 2008 research showed that the students $(54.03 \%)$ were not satisfied with conditions of start up loans and among other reasons they emphasized high interest rates (33.79\%) (Đorđević et al., 2010). The researches from 2010 and 2011 had similar indicators as previous two, $68.57 \%$, and $70.17 \%$ of the interviewed students would finance their own business from their own finances. Young people think that start up loans are not favourable $54.17 \%$ (2010) and 60.46\% (2011), and that the main problem represented high interest rates $48.07 \%$ (2010) and 4.,38\% (2011),
One of the reasons against business start up the interviewed students found in the lack of ideas (78.42) of them said this, which means that it is necessary to insist on development of entrepreneurial skills at faculties and high schools within promotion of entrepreneurial concept (Đorđević et al., 2010).The researches carried out in 2010 and 2011 showed that the reasons agaist business start up according to the interviewed students were: insufficient financial means $(29.43 \%)$ and $(26.77 \%)$ insecure political and economic situation $(20.38 \%)$ and $(23.99 \%)$. From these data can be concluded that the young still do not have enough self-confidence for starting their own business.There are several reasons for insufficient self-confidence of the young and one of them is education from the field of entrepreneurship which is still insufficient and inappropriate. There is a need for finding new ways of education and promotion of entrepreneurial concept. Young people in Serbia are still not enabled enough for development of entrepreneurial initiative and business start up. Another reason for lack of self-confidence of the young is inappropriate ambience for encouraging entrepreneurship of the young.

The research results from 2011 point at the fact that $55.95 \%$ of the interviewed students are not informed about the existence of stimulating funds for business start up.

The research results from 2011 show that the majority of students $(89.30 \%)$ think that in Republic of Serbia does not exist an appropriate ambience that stimulates the young for business start up. The main reasons for this, according to students, are: lack of financial means $(31.59 \%)$, unstable political and economic situation $(28.91 \%)$ and too high taxes $(23.77 \%)$. In the research from 2008 the students expressed dissatisfaction $(78.70 \%)$ with the ambience for encouraging young people for business start up. The most important factors which represent barriers related to business start up are the same as in the research from 2009. The only thing which is different is the sequence of reasons:unstable political and economic situation (36.54\%), long and complicated procedure of registration (13.75\%), as well as too high taxes (1.02\%) (Đorđević et al., 2010). These indicators point at the inappropriate state's policy towards the young as potential entrepreneurs, but towards a private entrepreneurship itself. Unstable political and economic situation, long procedure for getting registration and too high taxes have been repeated for two years in the similar research which points at the lack of appropriate ambience for business start 
up. When we add the lack of specialized institutions that would support the young to start their business then we come to the reasons for dissatisfaction with the ambience for encouraging the young to start business. Without appropriate ambience which will encourage the young for business start up it is not possible to encourage them seriously to behave entrepreneurially.

The majority of the interviewed persons in all researches from 2008 to 2011 considered that the state should have a key role in stimulating the young to start their business. The last research (2011) showed that $91.44 \%$ of the interviewed thought that the state should have a key role in stimulating the young to start their business. The interviewed extinguished the following supporting ways as the key ones: favourable loans, education and laws/regulations related to the young as entrepreneurs. Such an attitude was supported by $90.33 \%, 88.08 \%$, and $90.78 \%$ of the interviewed students in the research carried out in 2010, 2009 and 2008. The ways of support are the same, only their sequence is different.

\section{CONCLUSION}

Young entrepreneurs represent unused resource for development of national economies which is especially significant in the period of global economic crisis. Namely, according to statistic data in EU unemployment is in constant rise and unemployment of the young as well. Business start up represents one of the ways for reducing unemployment and revival of national economies. Europen Union has understood in time the importance of encouraging the young to start their own business because it has begun developing different programs for stimulating the young to go in entrepreneurship since 2000. However, as the situation on the market has changed the ways and initiatives of support have changed too.
Unfortunately, the young in Republic of Serbia are still not in the position to believe that their own business start up will be the best solution. The main reason is the lack of appropriate ambience on domestic market which would stimulate entrepreneurship. The problems like lack of financial means, too high taxes and unstable political and economic situation are making difficultes to the present entrepreneurs and discouraging the future ones.

Possible solution can be in creating the ambience for stimulating entrepreneurship with a special accent on the young. Creating the ambience is not only a task for the state but it should be the common task of the state and : Serbian Chamber of Commerce, Union od employers, universities, NGO, National Bank of Serbia and other interest bodies which understand that the young represent unused potential and resource for developing entrepreneurship and national economy as well.

\section{REFERENCES}

. Communication From the Commission: Annual Growth Survey 2012. (Vol. 1/5): European Commission 1.

. $€ 2.5$ billions to boost business competitiveness and SMEs 2014 - 2020. (2011). In E. Commission (Ed.), (Press release ed.): European Commission 2.

Euro area unemployment rate at $10.8 \%$. (2012). In Eurostat (Ed.), (News release - Euro Indicators ed., Vol. 52/2012): Eurostat.

Đorđević, D., Bogetić, S., \& Ćoćkalo, D. (2010). Razvoj preduzetničkog ponašanja kod mladih u Republici Srbiji. Megatrend revija, 7(2), 63-78.

Đorđević, D., Ćoćkalo, D., \& Bogetić, S. (2010). Preduzetničko ponašanje kod mladih - rezultati istrživanja u Srbiji (The Youth's Enterprising Behaviour - The Research Results From Serbia). Ekonomske teme (Economic Themes)(3/2010), 467-479.

Đorđević, D., Ćoćkalo, D., \& Đurin, S. (2011). Serbian Enterprises and Global Competition Challenges. Journal of Engineering Management and Competitiveness (JEMC), 1(1-2), 27-31. 